\title{
Role of the granulosa cells of the postovulatory follicle of the domestic fowl in oviposition
}

\author{
A. B. Gilbert, M. F. Davidson and J. W. Wells \\ Agricultural Research Council's Poultry Research Centre, \\ King's Buildings, West Mains Road, Edinburgh EH9 3JS, U.K.
}

\begin{abstract}
Summary. Surgical removal of the granulosa cells, leaving the remainder of the postovulatory follicle (POF) intact (including the thecal interstitial cells), resulted in delays of oviposition of about $19 \mathrm{~h}$; similar delays were obtained when the granulosa was left in situ but was damaged by the insertion of a silicone disc into the POF. The insertion of wax balls resulted in delays of 3-4 h but the granulosa appeared to be normal. It is concluded that the integrity of the granulosa is important for normal oviposition.
\end{abstract}

\section{Introduction}

It is now generally accepted that the avian postovulatory follicle (POF) is not homologous with the mammalian corpus luteum (see Gilbert, 1971). Nevertheless, the POF in the chicken is functional: its removal (Rothchild \& Fraps, 1944) or the ligation of its pedicle (Wood-Gush \& Gilbert, 1964) results in delayed oviposition of the egg derived from that follicle. These manipulations also affect the nesting behaviour associated with oviposition (Wood-Gush \& Gilbert, 1975). The mechanisms are not known: Wood-Gush \& Gilbert (1975) suggested that steroid hormones may be involved in the control of nesting behaviour whereas Tanaka (1976) and Tanaka \& Goto (1976) have produced evidence that a non-steroidal substance is involved in the regulation of oviposition.

Interpretation of the available experimental evidence is difficult because the POF has previously been treated as a whole, even though it is known to contain at least two types of what may be actively secreting cells--the thecal interstitial cells and the granulosa cells (see Gilbert, 1971). After ovulation the granulosa layer is easily removed from the thecal tissue by gentle scraping (Armstrong, Davidson, Gilbert \& Wells, 1977) and we have therefore examined the influence of the granulosa layer of the POF on oviposition by removing these cells.

\section{Materials and Methods}

A group of 60 hens derived from commercial light-hybrid layers (Babcock) was housed in commercial cages and supplied with food and water ad libitum. The cages were fitted with an automatic eggtiming recorder giving oviposition times to within $1 \mathrm{~min}$.

On any day (Day 1) a small group of birds (usually about 5) was selected randomly from the flock, and birds from this group were allocated randomly to various experimental or control treatments. The expected times of laying on the next (Day 2) and subsequent day were predicted from previous egg records obtained over a period of 6-8 weeks. On Day 2 the actual time of laying was compared with the predicted time and the birds were left for a period of $1 \mathrm{~h}$ after oviposition to ensure that they had ovulated (see Gilbert, 1967).

Surgery was then carried out under a general anaesthetic (Nembutal; Abbott Laboratories). An incision $6 \mathrm{~cm}$ long was made approximately parallel to the last rib and at a distance of $1 \mathrm{~cm}$ from it; the muscles were divided and the peritoneum opened to expose the caudal boundary of the ovary and the cranial regions of the oviduct. Ovulation was confirmed by the presence of a developing egg within the oviduct; the recent POF was identified by its size and general appearance and brought to the wound site. The POF was held open by Allis forceps while a standard spoon-shaped dental 
scaler was used to remove gently the granulosa which can be identified as a thin mucous-like covering on the inner surface of the follicle. To ensure complete removal of the granulosa cells the inner surface of the follicle was swabbed with small balls of cotton-wool. In the control birds similar scraping and swabbing were applied to the outer surface of the follicle. The follicle was then allowed to fall back into the peritoneal cavity and the wound was closed.

Oviposition on Day 3 was observed closely. If the bird laid within $24 \mathrm{~h}$ of its expected oviposition time it was immediately killed for examination of the ovary and oviduct. If oviposition did not occur within $24 \mathrm{~h}$ of the expected time the bird was killed without further delay.

\section{Results}

The results are given in Table 1. For control and experimental animals the comparison is made between the errors of prediction, i.e. the differences between the expected and actual oviposition times on the 2 days. The difference between the experimental and control groups for Day 2 was not significant nor was there any difference in the control group in the results for Day 3 when compared with those for Day 2. However, the difference between the results for Days 2 and 3 in the experimental group was highly significant $(P<0.001)$. Removal of the granulosa cells from the POF led to a delay of about $19 \mathrm{~h}$ in oviposition, a finding similar to that of previous work in which the whole POF was removed (Rothchild \& Fraps, 1944).

The follicle is innervated and contains structures resembling sensory receptors (Gilbert, 1965). Since the physical presence of granulosa cells in the POF may influence the timing of oviposition, attempts were made to simulate mechanical stimulation by inserting foreign objects in the POF after scraping. Silicone discs (10 mm diameter and $1-1.5 \mathrm{~mm}$ thick) were therefore inserted into the POFs

Table 1. The effect of surgery, either sham or for the removal of the granulosa, on Day $2,1 \mathrm{~h}$ after actual oviposition

\begin{tabular}{lccc}
\hline & $\begin{array}{c}\text { Day 2 } \\
\text { error of prediction } \\
(\mathrm{min})\end{array}$ & $\begin{array}{c}\text { Day 3 } \\
\text { error of prediction } \\
(\mathrm{min})\end{array}$ & $\begin{array}{c}\text { Differences in errors } \\
\text { between Days 2 and 3 } \\
(\mathrm{min})\end{array}$ \\
\hline $\begin{array}{l}\text { Control (sham-operated) birds } \\
\text { Mean } \pm \text { s.e.m. }(N=8)\end{array}$ & $43 \cdot 88 \pm 32 \cdot 4$ & $52 \cdot 25 \pm 28 \cdot 7$ & $-8 \cdot 38 \pm 44 \cdot 4$ \\
$\begin{array}{l}\text { Experimental (operated) birds } \\
\text { Mean } \pm \text { s.e.m. }(N=8)\end{array}$ & $9 \cdot 25 \pm 15 \cdot 7$ & $1132 \cdot 5 \pm 194 \cdot 7$ & $-1123 \cdot 5 \pm 125 \cdot 2$ \\
\hline
\end{tabular}

Comparison of birds before surgery, $t_{14}=0.962$ (N.S.).

Difference in errors: Control group hypothesis of no-effect, $t_{7}=\mathbf{0} \cdot 189$ (N.S.).

Differences in errors: Experimental group hypothesis of no-effect, $t_{7}=8.975(P<0.001)$.

Table 2. Effect on oviposition time (mean \pm s.e.m., no. of observations in parentheses) of inserting a foreign object into the postovulatory follicle with the granulosa intact or removed

\begin{tabular}{|c|c|c|c|}
\hline Insert & Granulosa & $\begin{array}{l}\text { Difference in errors } \\
\text { between Days } 2 \text { and } 3 \\
\text { (min) }\end{array}$ & $\begin{array}{l}\text { Histological state } \\
\text { of granulosa }\end{array}$ \\
\hline Wax ball & Intact & $209 \cdot 33 \pm 43 \cdot 4(3)$ & $\begin{array}{l}\text { Granulosa present and no visible } \\
\text { signs of damage or displacement }\end{array}$ \\
\hline Silicone disc & Intact & $872,1435(2)$ & $\begin{array}{l}\text { Granulosa present but damaged } \\
\text { and detached from one side of } \\
\text { POF }\end{array}$ \\
\hline Silicone disc & Removed & $1173 \pm 200 \cdot 8$ & $\begin{array}{l}\text { Sparse isolated groups of granulosa } \\
\text { cells }\end{array}$ \\
\hline
\end{tabular}


of control and experimental birds. In a similar way small balls of paraffin wax, about $0.4 \mathrm{~mm}$ in diameter, were inserted in other unscraped POFs.

No effect was found when discs were inserted into the granulosa-free POFs: the delays (Table 2) were comparable with those in Table 1 . However, insertion of the foreign bodies into the intact POFs did have an effect on oviposition. With the silicone disc there were delays of the same order as those caused by removal of the granulosa. With the wax balls, which were smaller than the discs, the delays in oviposition were only 3-4 h. Histological examination showed that in the silicone-disc birds considerable damage had occurred to the granulosa layer; in places the granulosa was detached from the theca, some of the cells were flattened and there was a partial accumulation of cells towards the base of the 'cup' of the POF. No damage was visible after inserting wax balls.

\section{Discussion}

It must be concluded that integrity of the granulosa is important to the function of the POF in respect of its role in oviposition. If the granulosa is removed, or even damaged, considerable delay in oviposition will result. From the evidence presented here, it might be tempting to ascribe to the granulosa the whole function of the POF and hence to relegate the thecal interstitial cells to a non-functional role. However, the possibility is not ruled out that the granulosa and thecal cells may both be required since either could produce a 'precursor' or 'initiating' substance which may activate the other, as has been shown for mammals (see Baird, 1977). Whatever the case, the importance of the granulosa cells in the function of the postovulatory follicle has been positively determined.

\section{References}

Armstrong, D.G., Davidson, M.F., Gilbert, A.B. \& Wells, J.W. (1977) Activity of $3 \beta$-hydroxysteroid dehydrogenase in the postovulatory follicle of the domestic fowl (Gallus domesticus). J. Reprod. Fert. 49, 253-259.

BaIRD, D.T. (1977) Evidence in vivo for the two-cell hypothesis of oestrogen synthesis by the sheep Graafian follicle. J. Reprod. Fert. 50, 183-185.

GilberT, A.B. (1965) Innervation of the ovarian follicle of the domestic hen. Q.J. exp. Physiol. 50, 437-446.

GilberT, A.B. (1967) Formation of the egg in the domestic chicken. Adv. Reprod. Physiol. 2, 111-180.

GilberT, A.B. (1971) The endocrine ovary in reproduction. In The Physiology and Biochemistry of the Domestic Fowl, vol. 3, pp. 1149-1468. Eds D. J. Bell \& B. M. Freeman. Academic Press, London.
RothCHILD, I. \& FRAPS, R.M. (1944) On the function of the ruptured ovarian follicle of the domestic fowl. Proc. Soc. exp. Biol. Med. 56, 79-82.

TANAKA, K. (1976) Oviposition inducing activity in the ovarian follicle of different sizes in laying hens. Poult. Sci. 55, 714-716.

Tanaka, K. \& Goto, K. (1976) Partial purification of the ovarian oviposition inducing factor and estimation of its chemical nature. Poult. Sci. 55, 1774-1778.

Wood-Gush, D.G.M. \& GilberT, A.B. (1964) The control of the nesting behaviour of the domestic hen. Il. The role of the ovary. Anim. Behav. 12, 451-453.

Wood-Gush, D.G.M. \& GilberT, A.B. (1975) The physiological basis of a behaviour pattern in the domestic hen. Symp. zool. Soc. Lond. 35, 261-276.

Received 23 May 1977 